3. Yefymenko $V . V$. Influence of processing of reactive fuels with neutral gases on their fire safety, thermal oxidation stability and cavitation properties: Ph. D. thesis in eng.: spec. 05.17.07 «Chemical technology of fuels and lubricants» / Iefymenko V. V. - K.:2007. - 172 p.

4. Aviation Chemmotology: Fuel for Aviation Engines. Theoretical and engineering basics of application: textbook / N. S. Kulik, A. F. Aksenov, L. S. Yanovsky, C. V. Boichenko. - K.: NAU, 2015. - 560 p.

DOI: doi.org/10.18372/38233

UDC: $621.892 .6: 504(043.2)$

\title{
2.10 IDENTIFICATION AND ASSESSMENT OF BIOLOGICAL RISK OF AVIATION FUEL SUPPLY
}

\author{
Iryna Shkilniuk ${ }^{1}$, Sergii Boichenko ${ }^{1}$, Tetiana Kondratiuk ${ }^{3}$, Nataliia Shevchuk $^{2}$
}

Aviation fuel supply exists as much as aviation is more than a hundred years. Fuel is the blood of an aircraft. The mass of fueled jet fuel is up to $70 \%$ of the maximum take-off weight of modern aircraft. The main link in all civil aviation activities is flight safety. The most important condition for ensuring the safety of flights is the use of aircraft in the range of expected operating conditions, taking into account operational limitations established in the norms of airworthiness.

Now ICAO is disturbed formed by the world tendency of entering of contaminated aviation fuel in airport. Many documents ICAO, IATA and Joint Inspection Group focuses on pollution fuels. ICAO issued a directive DOC 9977 «Guide to the supply of aviation fuel in civil aviation» and IATA issued EI/JIG STANDARD 1530 «Quality assurance requirements for the manufacture, storage and distribution of aviation fuels to airports». The essence of these documents is that all parties involved are jointly responsible for ensuring the quality, purity and possibility of quality control at every stage of production, supply and operation of aviation fuel.

Fuel and air machinery loss during operation are major aircraft losses for modern aircraft. The main factors and parameters that determine the indicated losses in operation are flight path, speed and altitude; equipment reliability; fuel conditioning.

The study of theoretical and practical aspects of risk, its analysis and assessment is becoming increasingly relevant, because the risk in today's economic environment has a significant impact on the results of enterprises.

The active study on microbial growth in the composition of petroleum fuels began in the USA during the creation of jet aircraft.

During the creation of jet aviation in the USA, began active study of questions connected with microorganisms' development in oil fuels. The work on this question in our country mainly was to determine fuels biostability in laboratory conditions. Purposeful researches of fuels biostability in operating conditions were not conducted practically [1].

In 1956, the United States Air Force recognized that its widely-used JP-4 fuels were microbial contaminated when Air Force B-47 and KC-97 flight operations were affected. Two years later, a B-52 crash was directly attributed to clogging of fuel system screens and filters by some form of fuel contamination. In that same year, the Wright Air Development Center determined that sludge accumulation in tanks used to store kerosene-type fuels was a common occurrence [2].

More instances of contamination and corrosion surfaced in the late 1950's and early 1960's and reached near epidemic proportions in storage tanks and aircraft fuel cells at various locations. At the beginning of 1962, approximately 52 governmental and non-governmental agencies were involved in various phases of research on microbiological contamination of fuels.

The modern world legislation raises the level of requirements for quality aviation fuels. In 2012, the International Civil Aviation Organization has developed directive 9977/AN 489 
«Guidelines for the supply of aviation fuel for civil aviation», which focused on the clean air fuels, including microbiological contamination.

Air transport is a major consumer of high-quality fuels and lubricants. For large scale high oil consumption issue efficiency of aviation technology, economy and management of aviation fuel has an important public and economic value. The efficiency and reliability of the fuel system software greatly depends on the quality of aviation fuel. The largest number of failures and malfunctions elements of the fuel system, engine and aircraft related to fuel quality and purity.

A limited amount of oil resource, the introduction of ICAO and IATA standards, satisfaction of safety and operational safety requirements, economic indicators, financial profitability require a risk-based approach in aviation fuel supply [3].

The risk indicator is introduced for the quantitative characteristics of the safety of objects. Risk is a measure of danger. The analysis of the threats to sustainable aviation fuel supply is to identify all sources of threat and assess their impact on flight safety.

The process of performing risk analysis has traditionally consisted of the following consecutive procedures $[4,5]$ :

- planning and organization of work;

- identification of risks;

- risk assessment;

- development of risk management recommendations.

The key stages in the risk analysis process are the identification of risks and their classification. At the risk identification stage, the risks that exist at different stages of the jet fuel cycle life were analyzed [5].

Stages of the fuel life cycle:

1) oil recovery stage;

2) oil refining stage;

3) stage of production of commodity jet fuel;

4) stage of jet fuel transportation;

5) jet fuel storage stage;

6) fuel use stage.

Specific aspects can be distinguished from the point of view of the chemmotological reliability. One of them is the purity of fuel, the presence or absence of mechanical impurities, water, microorganisms and other contaminants that should not be present in the fuel when shipped from production sites, but which can accumulate during transportation, storage, pumping and other operations.

There are many risks in the production of fuels, including the risk of microbiological contamination. The hydrocarbon component is the most dangerous raw material from this point of view. On the one hand, this is the basis of fuels, on the other is the source of potential infection of microbiological oil destructors.

Destruction of materials usually occurs under the influence of not a single group of microorganisms and an entire complex including bacteria and fungi. One group of microorganisms of its own activity prepares a substrate for another. The process is very complex and is due to a large number of factore. The substrate is of paramount importance, it forms the formation of such substrates new, functionally interconnected units, as a microbial association or biocenosis.

The biological risk factor can be defined as biological matter capable of self-replication and which can have a destruction effect on the fuel.

Microbes may be introduced into fuels as products cool in refinery tanks. Bacteria and fungi are carried along with dust particles and water droplets through tank vents. In seawater ballasted tanks, microbes are transported with the ballast. Vessel compartments ballasted with fresh, 
brackish, or seawater, all of which may contain substantial numbers of microbes, may easily become contaminated with the microbes transported with the ballast water [6].

Today it is known 200 species of microorganisms, including 30 families that can use hydrocarbons as sole source of carbon and energy (Fig. 1). These include bacteria, yeast and fungi.

Table 1

The main microorganisms, that cause biocontamination of fuels



Active development of the fuel and the fuel systems of microscopic fungi (Hormoconis resinae, his types. Penicillium, Aspergillus fumigatus, Paecilomyces variotii, etc.) recognized the most dangerous. Fungi form a dense mycelium, the accumulation of which not only clog pipelines and fuel filters, but also create numerous localized areas of corrosion on the surfaces of fuel systems. A most active destructor of aviation fuel until recently was recognized Cladosporium resinae (modern name Hormoconis resinae or Amorphoteca resinae) of microscopic fungi. This socalled «kerosene» fungi [7]. Today this group classified as fungi Monascus floridanus, which is inherent in the ability to develop rapidly in the aviation fuel [4]. Fungi have some morphological, 
physiological and genetic features, good with which they occupy the dominant position among organisms causing biological damage.

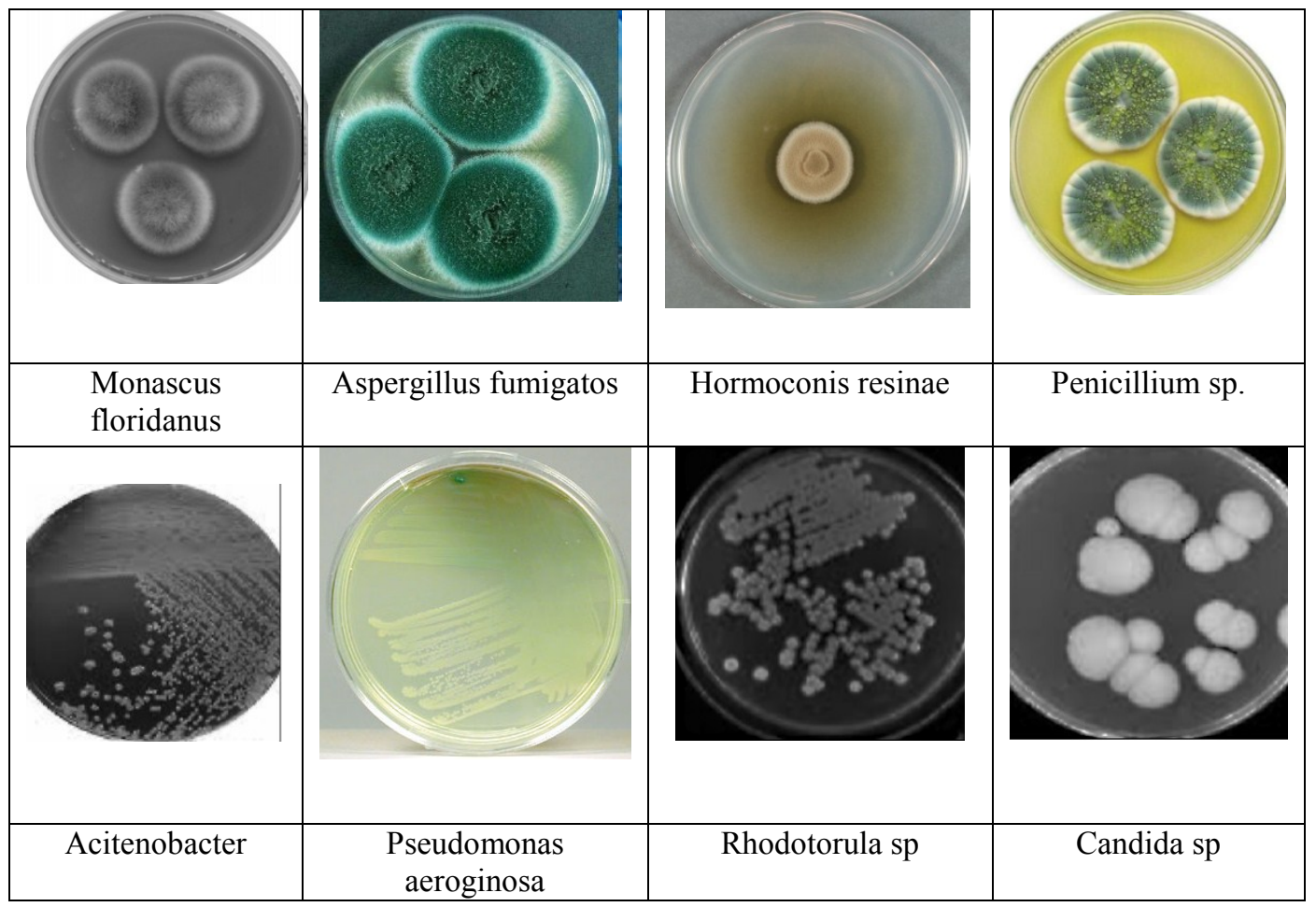

Fig 1. The main strains of microorganisms-petroleum product destroyers.

The first stable products of hydrocarbons oxidation are the primary alcohols. The next is usual biological conversion of alcohols to aldehydes and aldehyde to acid [8]. The general scheme of reactions:

$$
\mathrm{R}-\mathrm{CH}_{2}-\mathrm{CH}_{3}+[\mathrm{O}] \rightarrow \mathrm{R}-\mathrm{CH}_{2}-\mathrm{CH}_{2} \mathrm{OH}-2 \mathrm{H} \rightarrow \mathrm{R}-\mathrm{CH}_{2}-\mathrm{CHO}-2 \mathrm{H}+\mathrm{HOH} \rightarrow \mathrm{R}-\mathrm{CH}_{2}-\mathrm{COOH} .
$$

Microorganisms have the selective ability related to various hydrocarbons, and this ability is determined not only by the difference in the structure of substance, and even the number of carbon atoms that are the part of their structure.

It is proved that microbial contamination of fuel is connected to microbiological enzymatic oxidation of hydrocarbons with formation of organic acids that have surface active properties. The speed and depth of the microbial oxidation of aviation fuel depend on their carbohydrate composition. Hydrocarbons with a linear structure of the molecules are destroyed faster than their branched isomers. Aliphatic hydrocarbons (paraffin's) are less biostable than aromatic. Therefore, fuels that contain mostly paraffin hydrocarbons can be destroyed by microorganisms faster than those containing more aromatic compounds. Cycloalkanes are more difficult to microbiologically destruction than alkanes, due to the presence of a cyclic structure that is heavier than oxidation. Strains that are capable of biodegradation of cyclic alkanes include bacteria of the genera Cordonia, Xanthobacter, and others. Seams that are capable of biodegradation of cycloalkanes have specific enzyme systems that are different from the enzyme systems used by microorganisms to oxidize non-cyclic alkanes. 
The research of activity of growth of active and potential destructors spent in fuel by the value of the accumulation of biomass after a month of cultivation (Fig. 2). The greatest value of biomass is defined for the Hormoconis resinae isolated from the tank of the aircraft.

The ability to grow potential destructors for various hydrocarbons was studied. Micromycetes grow on all tested liquid hydrocarbons, except for hexane [9]. The tendency to increase in hydrocarbons with more long carbon chains $\left(\mathrm{C}_{10}-\mathrm{C}_{17}\right)$ was observed in Hormoconis resinae and Monascus floridanus. The greatest importance of biomass increase in Hormoconis resinae was observed on heptadecane $\left(\mathrm{C}_{17} \mathrm{H}_{36}\right)$, Monascus floridanus on hexadecan $\left(\mathrm{C}_{16} \mathrm{H}_{34}\right)$.

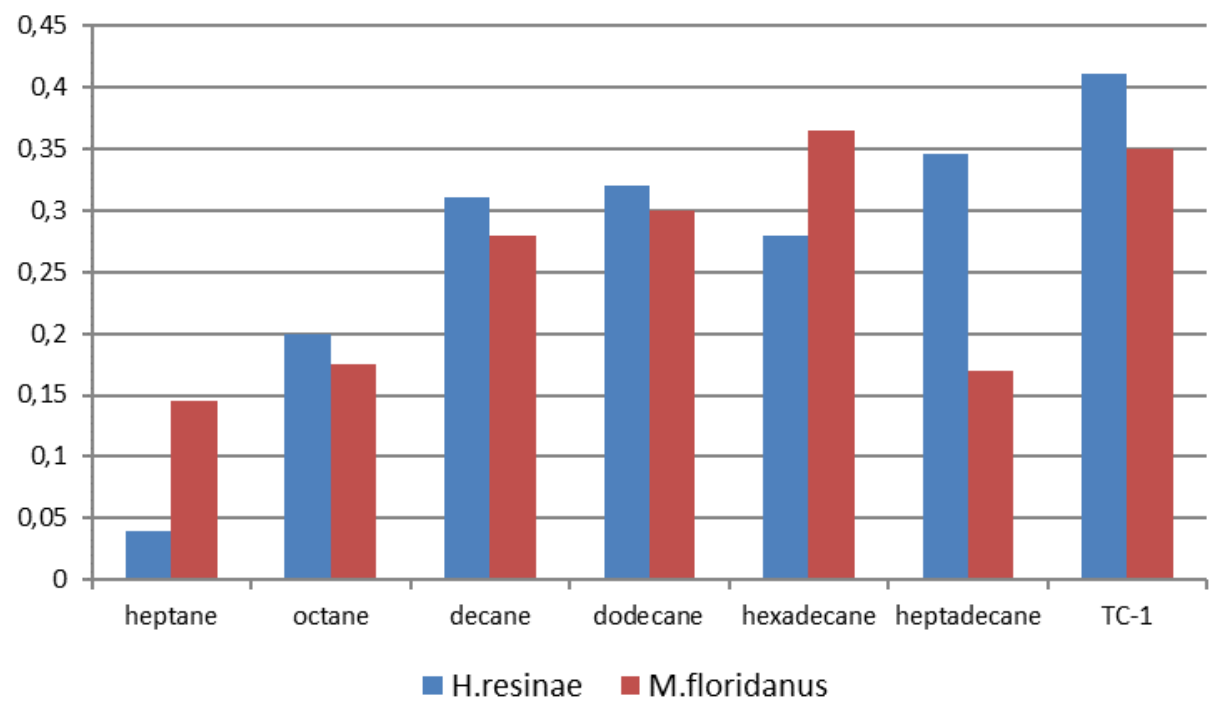

Fig. 2. Biomass of active destructors after a month growth in hydrocarbons

After arriving in fuel tanks, microorganisms may either stick to overhead surfaces or settle through the product. Some microbes will adhere to tank walls, whereas others will settle to the fuel/water interface (Fig. 3). Most growth and activity takes place where fuel and water meet. The tank bottom fuel/water interface is the most obvious fuel/water boundary. However, there is also a considerable area of fuel/water interface on the interior surface of tank-shells. Microorganisms require water for growth. Although bacteria and fungi can be present in the fuel phase, their growth and activity is restricted to the water phase of fuel systems. The water phase includes volumes ranging from trace (several $\mu \mathrm{L}$ ) to bulk $\left(>1 \mathrm{~m}^{3}\right)$ accumulations and water entrained within deposits that accumulate on system surfaces. Typically, fuel and system deterioration is caused by the net activity of complex microbial communities living within slimy layers called biofilms. Biofilms may be found on tank roofs, shells, at the fuel/water interface, and within bottom sludge/sediment [6].

The high temperature characteristic of distillation and other refinery processes sterilize refinery stocks used in fuel blending. However, conditions in refinery tankage, transport systems, terminal tankage, and users' system tankage may lead to microbial contamination and possible biodeterioration.

In refinery tankage, water can condense and coalesce as product cools. Tank vents draw moisture from the outside atmosphere and may allow precipitation to enter the tank.

Moreover, product withdrawal creates a partial vacuum that pulls pollen, dust, and other microbe-carrying particulates through tank vents. Consequently, refinery products tanks are the first stage of petroleum handling where significant microbial contamination can occur. 


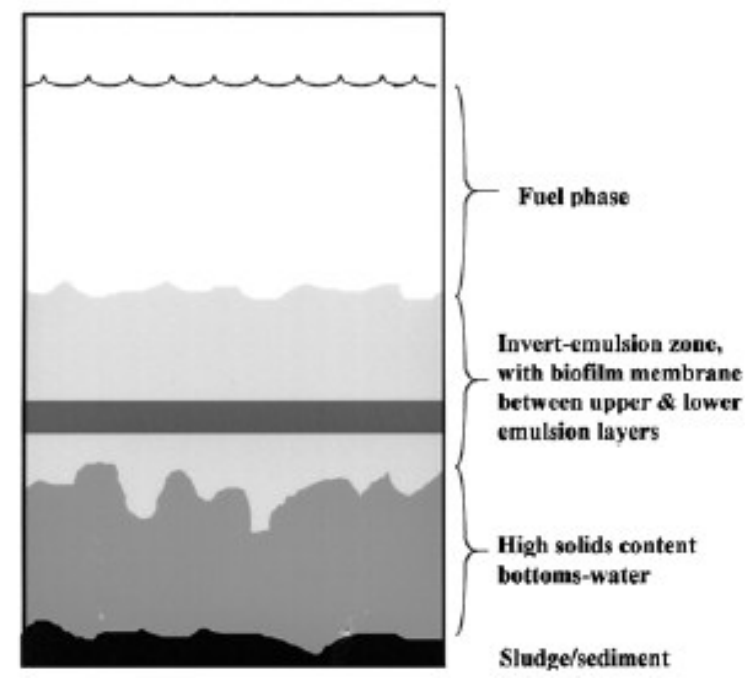

Fig. 3. Schematic of Fuel Tank Bottom Sample with Significant Microbial Contamination and Biodeterioration

In transport by means of tanker or pipeline, additional water may be introduced by condensation. In contrast to pipelines, condensate is not the major source of additional water. Rather, inadequate cargo compartment stripping, use of water as false bottoms to facilitate complete cargo discharge, and other incidental, intentional water use provide substantial water to fuel tanks. Biofilms can form on tanker or pipeline surfaces where they entrain water, inorganic particles, and nutrients to support growth. Such growth can slough off and be carried to terminal and end user tankage. In terminal tanks, turnover rates may be a week or longer, allowing particulates (including biofilm flocs) to settle into the sludge and sediment zone before product is drawn from the tank. As turnover rates increase, the likelihood of drawing biomass with fuel also increases, due to reduced settling times. Population densities of less than two million cells $/ \mathrm{mL}$ will have no effect on fuel clarity. Consequently, contaminated fuel is rarely detected visually at the terminal rack.

The places of microbiological colonies development of on the fuel life cycle are established during the analysis of biological risk of aviation fuel supply. The places of microbiological colonies are presented in Fig. 4 [6].

Microbes require water as well as nutrients. Consequently, they concentrate at sites within fuel systems where water accumulates.

Water is essential for microorganisms' growth and proliferation. Even negligible traces of water are sufficient to support microbial populations.

Nutrients are divided into macro-nutrients and micronutrients. Carbon, hydrogen, oxygen, nitrogen, sulfur, and phosphorus (CHONSP) comprise the macro-nutrients, and most of these are readily available in fuels. Only phosphorous is likely to be growth limiting in most fuel systems. A variety of elements, including calcium, sodium, potassium, iron, magnesium, manganese, copper, cobalt, nickel, and other metals, are required in trace quantities. None of these elements is limiting in fuel systems. Fuel systems that provide both the requisite water and nutrients will support microbial growth and proliferation.

The rate of microbial growth increases with increasing temperature within the physiological range (temperature range within which growth occurs) of a given microorganism. Microbes are generally classified into three groups, based on their temperature preferences/requirements. Some 
microbes require low temperatures $\left(<20{ }^{\circ} \mathrm{C}\right)$. Others thrive in superheated environments $\left(>100{ }^{\circ} \mathrm{C}\right)$. However, the physiological range of the microbes most commonly recovered from fuel tanks is $0{ }^{\circ} \mathrm{C}$ to $35^{\circ} \mathrm{C}$, with growth optimal between $25^{\circ} \mathrm{C}$ and $35^{\circ} \mathrm{C}$.



Fig. 4. Fuel supply scheme (arrows indicate sites where water and biologicals tend to accumulate): (a) refinery distillation towers, $(b)$ refinery product tanks, (c) fuel transportation pipeline (low points in pipeline trap water), $(d)$ distribution terminal tanks, $(e)$ commercial dispensing rack and tank truck, $(f)$ retail/fleet underground storage tank, $(g)$ retail/fleet dispensing system.

The some strains of Hormoconis resinae are capable of developing in a fuel at a temperature of $50{ }^{\circ} \mathrm{C}$ and the strains of Aspergillus fumigatus survive in aviation kerosene up to $80{ }^{\circ} \mathrm{C}$. The growth of Hormoconis resinae in aviation fuel is fixed at a temperature of $28{ }^{\circ} \mathrm{C}$. The activity of mushrooms decreases with increasing or decreasing temperature (Table. 2).

Table 2

The growth of fungi in fuel at positive temperatures (in points)

\begin{tabular}{|c|c|c|c|c|c|}
\hline \multirow[b]{2}{*}{ Fungi } & \multirow{2}{*}{$\begin{array}{l}\text { The time the } \\
\text { manifestation } \\
\text { of signs of } \\
\text { growth, days }\end{array}$} & \multicolumn{4}{|c|}{ The temperature, ${ }^{\circ} \mathrm{C}$} \\
\hline & & 9 & 18 & 28 & 36 \\
\hline \multirow{3}{*}{$\begin{array}{l}\text { Hormoconis } \\
\text { resinae }\end{array}$} & 7 & 0 & 0 & 0 & 0 \\
\hline & 14 & 0 & 1 & 2 & 0 \\
\hline & 21 & 1 & 2 & 3 & 1 \\
\hline \multirow[t]{3}{*}{ Phialofora $s p$} & 7 & 0 & 0 & 2 & 0 \\
\hline & 14 & 1 & 2 & 4 & 2 \\
\hline & 21 & 2 & 2 & 4 & 3 \\
\hline
\end{tabular}

0 - no signs of growth, 1 - turbidity of the water layer, the formation of precipitation, 2 - the appearance of large flakes in the water layer, 4 - the formation of small clots, 5 - the formation of large clots.

The risk of uncontrolled microbial contamination is generally greatest in tropical regions. However, in the absence of adequate housekeeping practices, microbial contamination problems can also occur in fuel systems located in cold climates.

Water $\mathrm{pH}$ is generally not a controlling factor in fuel systems. Most contaminant microbes can tolerate $\mathrm{pH}$ 's ranging from 5.5 to 8.0. As with temperature, there are microbes that prefer acidic environments (some grow in the equivalent of $2 \mathrm{~N}$ sulfuric acid) and others that grow in alkaline systems with $\mathrm{pH}>11$. Fuel tank bottom-water $\mathrm{pH}$ is usually between 6 and $9[6,8]$. 
As water activity tends to be greatest at interface zones, this is where microbes are most likely to establish communities, or biofilms. Numbers of microbes within biofilms are typically orders or magnitude greater than elsewhere in fuel systems. Biofilms can form on tank overheads, at the bulk-fuel, bottom-water interface, and on all system surfaces.

Using fuel hydrocarbon vapors as their carbon source, microorganisms can colonize tank overheads, where condensation provides the necessary water activity. Biofilms on overheads generally look like slimy stalactites.

Whereas a $1-\mathrm{mm}$ thick biofilm on a tank wall may seem negligible, it is 100 times the thickness of most fungi, and 500 to 1000 times the longest dimension of most bacteria. This seemingly thin film provides a large reservoir for microbial activity. Within the biofilm microenvironment, conditions can be dramatically different from those in the bulk product.

Microorganisms consortia (communities) give the biofilm community characteristics that cannot be predicted from analysis of its individual members.

Microorganisms are able to consume hydrocarbons directly excrete waste products that other consortium members use as food. The net effect is a change in $\mathrm{pH}$, oxidation-reduction (or redox) potential, water activity, and nutrient composition that has little resemblance to the environment outside the biofilm [6].

Microbes growing anaerobically produce low molecular weight organic acids (formate, acetate, lactate, pyruvate, and others). These acids accelerate the corrosion process by chemically etching the metal surface. There are data demonstrating that biofilm communities can deplasticize the polymers used in fiberglass synthesis. Such activity can result in catastrophic tank failure and is most likely to occur along the longitudinal centerline (the same place of the greatest frequency of MIC pinholes).

Biosurfactants facilitate water transport into the fuel phase and some fuel additive partitioning into the water phase. Other metabolites may accelerate fuel polymerization. Produced at concentrations that are difficult to detect against the complex chemistry of fuel components, these metabolites can have a significant deleterious effect on fuel stability. Although most of the change occurs within a few centimeters of the biofilm-fuel interface, product mixing can distribute metabolites throughout the fuel system.

More particularly after microbiological contamination of aviation fuels the following effects are observed in the presence of the above-mentioned favorable conditions [9]:

- change in physical and chemical properties of fuels, namely increasing of major physicalchemical parameters values as kinematic viscosity, refractive index, $\mathrm{pH}$, content of actual resins and others. Also characteristic features are the formation of sediment, turbidity fuel and peculiar odor;

- corrosion of storage tanks for aviation fuels. Corrosion development of bottom part where accumulates water sludge, especially on verge of system distribution "fuel-water", corrosive damage of aircraft tanks, corrosion of aircraft power constructions;

- clogging and damage of fuel filters, pumps and fuel systems. Sedimentation of mycelium and bacteria colonies at the inner walls of the fuel systems leads to clogging of pipelines, filters, pumps and fuel systems;

- threat to the safety of aircrafts flights. Changing the physical, chemical and exploitation properties of aviation fuels leads to early clogging of filters, pollution of regulating equipment, causing unstable operation of the fuel system, and therefore can cause failure of the engine, and even complete failure of the system, and as a consequences is appearance of accidents and emergency landings.

The changing the acidity of fuel is an important consequence of the proliferation of microorganisms (Fig.5). Acidity of fuel due to the presence of organic or inorganic acids or their derivatives. Therefore, the change in $\mathrm{pH}$ value of the fuel can indirectly determine the dynamics of microbial growth in fuel. The acidity of the fuel due to their content of organic acids and cidic 
compound. This quality index characterises the presence of the fuel products that provoke an increase in the rate of wear and corrosion of engine friction pairs and the air supply system, as well as corrosion of tanks, pipes and fittings. The metabolic products of microorganisms destructors fuels contain organic acids and increase the acidity of fuels.

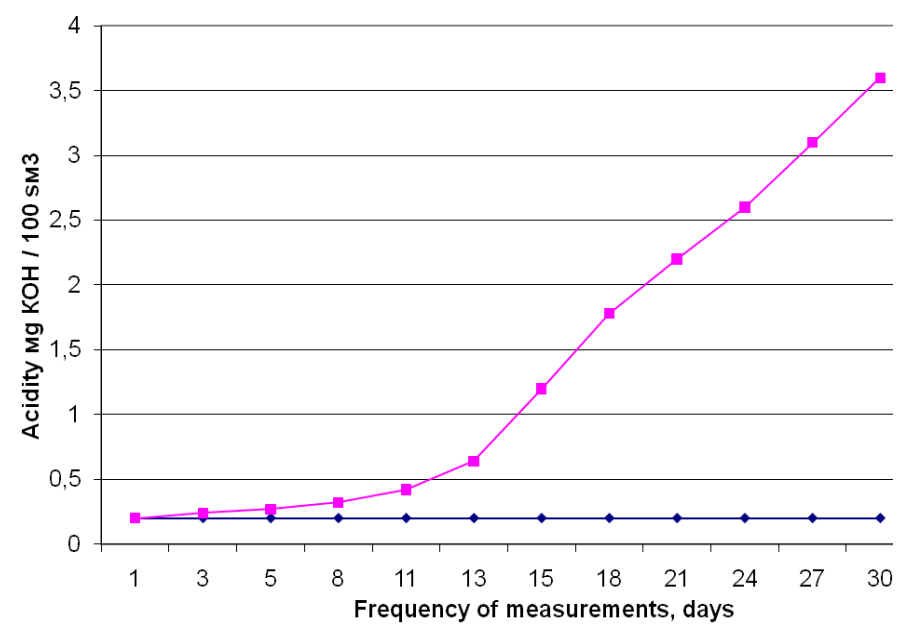

Fig. 5. Change jet fuel acidity under the influence of microbiological contamination $\square$-research sample $\square$ - check sample

The aviation industry is experiencing increasing pressure from the public and environmentalists who say that the increase in traffic volume and number of aircraft operated by causing serious damage to the environment, besides aviation is one of the largest consumers of fuel and lubricants. Necessary to replace petroleum hydrocarbons alternative raw materials. Carbon biomass carbon cheaper oil. However, the conversion of the «cheap» carbon in the consumer goods while expensive. Before commissioning, the risk and the effect on reliability of equipment should be evaluated.

Biocomponents is a materials derived from the lipids of plants or animals, which can be used directly in existing combustion engines. In a base catalyzed process, triglycerides are broken down through the transesterification of the ester bond linking the glycerol backbone with the fatty acids. Through methanolysis, glycerol is substituted with a methyl group to produce single chain fatty acid methyl esters (FAME). FAME are structurally similar to petroleum alkanes and furthermore have suitable physical and chemical properties, which allows for use it in engines.

There are problems with biocomponents which need to be addressed before biocomponents become a fully viable alternative to fossil fuels. The problem is the higher propensity of biocomponents towards microbial contamination compared with petroleum hydrocarbon.

Biocomponents and petroleum hydrocarbons have similar calorific values, similar viscosities, similar densities and similar material compatibilities. However, despite these similarities, biocomponents with fuels are significantly more susceptible to bio-contamination. Studies have shown that biocomponent has a higher amount of microbial contamination, higher rate of microbial induced fuel degradation and higher rate of Microbial Induced Corrosion (MIC) of fuel system components compared to petroleum fuel. The high propensity for contamination of biofuels is likely due to several factors. The major issue deals with the hygroscopicity of biocomponent (i.e., it absorbs water from the atmosphere). Water may also occur as emulsions in biodfuel as a remnant of the transesterification process. Another factor is the higher bioavailability of biocomponent. Biofuels easily hydrolyzes to fatty acids by both chemical and microbial reactions. Fatty acids are important for every living organism and are easily incorporated into the 
tricarboxylic acid (TCA) cycle metabolism via $\beta$-oxidation. This bioavailability is a somewhat double-edged sword: while it makes use of biocomponent more difficult on a daily basis, biocomponent degrades in soil and water environments in a few days, diminishing the environmental impact of fuel spills.

Studies of microbiological stability of aviation fuels have been carried out in the laboratory of the Ukrainian Scientific-Research Center of Chemmotology and certification of fuel and technical liquids. Samples of fuels were submitted jet fuel «TC-1» and automobile gasoline A-95 (tabl. 3). The methyl ester of fatty acids of sunflower oil was selected as the bio-component jet fuel «TC-1». Gasoline A-95 has been selected as an alternative to leaded aviation gasoline. Ethanol was added in different concentrations to gasoline [9].

Table 3

List of samples

\begin{tabular}{|c|l|}
\hline $\begin{array}{c}\text { Number } \\
\text { of samples }\end{array}$ & \multicolumn{1}{|c|}{ Samples } \\
\hline 1 & Jet fuel «TC-1» \\
\hline 2 & Jet fuel «TC-1»+10\% biocomponent \\
\hline 3 & Jet fuel «TC-1»+20\% biocomponent \\
\hline 4 & Jet fuel «TC-1»+30\% biocomponent \\
\hline 5 & A-95 \\
\hline 6 & A-95+5 $\%$ ethanol \\
\hline 7 & A-95+10 \% ethanol \\
\hline 8 & A-95+15\% ethanol \\
\hline 9 & Biocomponent \\
\hline
\end{tabular}

The test specimens were infected colonies microorganisms and control samples are placed in a lit environment with ambient temperature $20-25^{\circ} \mathrm{C}$. The studies were conducted 2 weeks. Control of changes were made every week on visual and chemical methods. The acidity of fuel was chosen as the chemical method of control microbiological growths. The choice of rate is due to the mechanism of microbial degradation and metabolism products biodestruktors. The change of the value of the indicator will be judged on the impact biocontamination quality fuels, fuels and microbiological stability of the rate of growth of microorganisms.

The essence of the method lies in the titration of the acidic compounds of the test product with an alcoholic solution of potassium hydroxide in the presence of a color indicator. Acid number is expressed in $\mathrm{mg} \mathrm{KOH} / 100 \mathrm{~cm}^{3}$. This is standart method [11]. Determination of the acid number performed in the semi-automatic titrator 702 SM Titrino Mettler Toledo.

Test results are presented in Fig. 6. The values on the vertical axis of the diagram of Fig. 1 is the acidity, expressed in $\mathrm{mg}$ of $\mathrm{KOH} / 100 \mathrm{~cm}^{3}$ of fuel.

Biocomponents such as the methyl ester of fatty acids of sunflower oil is subject to the same biodegradation by microorganisms like jet fuel.

Corrosive activity of aviation fuels is estimated by such indicators as acidity, tests on a copper plate, the content of water-soluble acids and alkalis, water content, sulfur content, etc. The test on a copper plate is a universal method for qualitative evaluation of corrosion activity of 
aviation motor fuels. Increased corrosion of fuels with microbiological contamination is confirmed by the results of experiments carried out in Test interactive laboratory «AviaTest» by the index of copper plate.

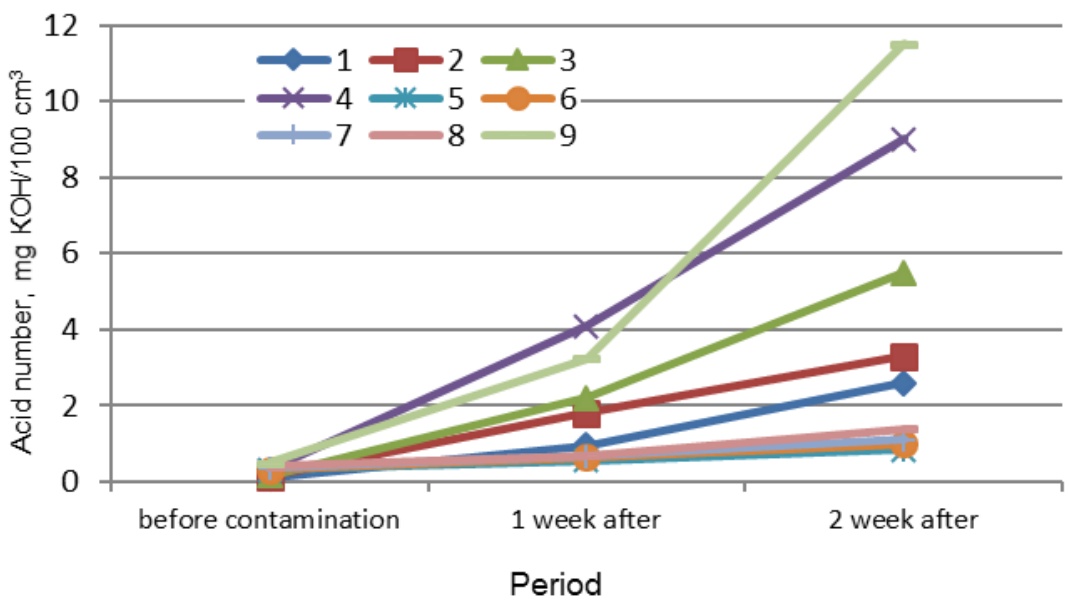

Fig. 6. The change of acidity of traditional and alternative fuels under the influence of microbiological contamination

The gist of the method is as follows. The prepared copper plate is immersed in a certain amount of sample, heated and kept at a temperature of $100{ }^{\circ} \mathrm{C}$. for 3 hours. After this time, the plate is removed, washed and compared with standards of corrosion.

The list of samples and results of their tests is presented in Table 4.

Table 4

List of samples for research and test results

\begin{tabular}{|l|l|}
\hline \multicolumn{1}{|c|}{ Sample } & The test result \\
\hline Clean fuel for jet engines «TC-1» & \\
\hline Clean fuel for jet engines Jet A-1 & \\
\hline Fuel for jet engines «TC-1» with microbiological pollution & \\
\hline Fuel for jet engines Jet A-1 with microbiological pollution
\end{tabular}

The results of research have shown that fuel for jet engines with microbiological contamination has increased corrosion properties. The appearance of dark plaque and changes in color on the plates are very noticeable. The appearance of copper plates, which were kept in fuels for jet engines with signs of microbiological contamination, does not correspond to reference samples.

Corrosion occurs under the influence of the products of vital activity of microorganisms present in fuels. The fungi and many bacteria form ammonia, hydrogen sulfide, and various organic acids in the process of metabolism, most of which are characterized by high corrosive activity (Fig. 
7, tabl. 5). In the course of its development, microorganisms destroy inhibitors that protect metal and stimulate its corrosion. Microorganisms are acceptors on the surface of metals. Corrosion of metal products, structures usually occurs in conditions of high humidity in the presence of contamination.

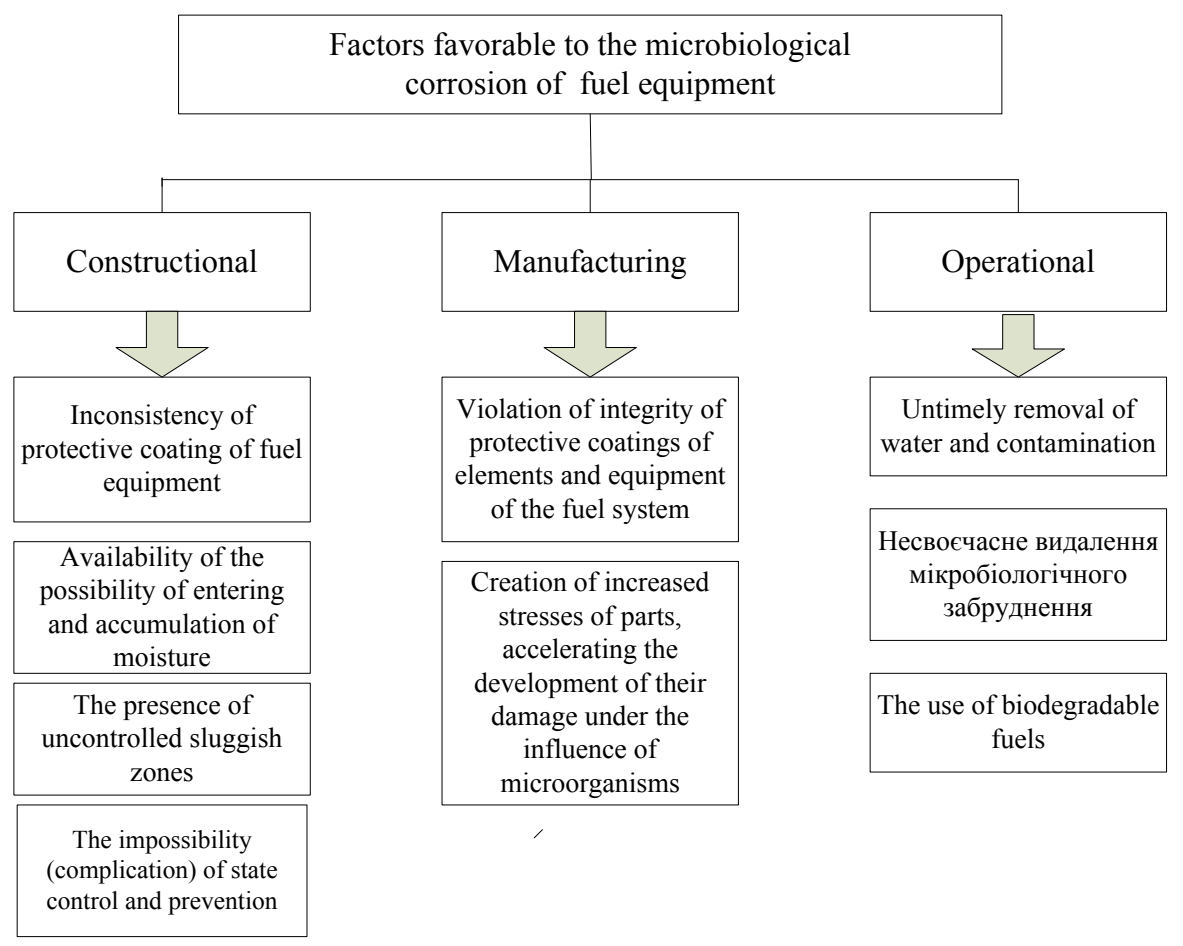

Fig. 7. The causes of microbiological corrosion.

The corrosion is one of the most dangerous types of metal destruction of aircraft structures. Over $50 \%$ of all corrosion processes due to the influence of microorganisms. The causes of corrosion are analyzed. The effect of microbial contamination in aviation fuel on their corrosive properties are investigated and described in these materials. The conclusion that biocorrosion of the fuel system and aircraft structures is part of the problem fuel with microbiological contamination are made and justified in these materials.

There are many ways to prevent biological contamination of fuels. One of such method is the method of ultraviolet and electromagnetic radiation. Ultraviolet radiation causes the death of microorganisms. For this purpose the UV lamp was developed. During its development excluded the possibility of explosion and inflammation of fuels. The lamp can be mounted to the bottom of the fuel tank and move along it, as well as along the fuel line.

Possible installation of lamps during pumping fuel from one tank to another. Destruction of microorganisms is also possible by using electromagnetic radiation at a certain frequency radio waves [8]. Colonies of fungi and bacteria can be removed by filtration through a porous material, the pore size of which is not more than 2 microns. Possible way to protect the fuel through bacterial filters, filled with silver compounds (for example, cotton, glass, synthetic rubber).

To physical and mechanical methods of microbiological contamination control are also include centrifugation followed by agglomeration filtration, flotation, the use of ion-exchange resins, electro hydraulic deposition, ultrasonic control $[6,8]$. 
The most effective way to protect the fuel from biological contamination at present is biocide additives that reduce activity of microorganisms in jet fuels and prevent biological corrosion of fuel tanks $[1,5]$.

Table 5

Potential consequences caused by microorganisms in aviation fuel systems

\begin{tabular}{|l|l|}
\hline \multicolumn{1}{|c|}{ Risks } & \multicolumn{1}{c|}{ Principal Types of Microorganisms } \\
\hline Blockage of pipes, valves, filters & Fungi; polymer-producing bacteria \\
Increased water content & All \\
Sludge formation & All \\
Surfactant production & Fungi; and aerobic bacteria \\
Corrosion of storage tanks and lines & Fungi; and anaerobic bacteria \\
Production of suspended solids in the fuel & All \\
Breakdown of hydrocarbons & Fungi; and aerobic bacteria \\
Shortened filter life & All \\
Fouling injectors & Aerobic bacteria and fungi \\
Increased sulfur content of fuel & Sulfur-reducing bacteria (SRB) \\
Shortened life of engine parts & Undetermined \\
Penetration of protective tank & Fungi \\
Health problem & Endotoxing-producing bacteria, SRB \\
\hline
\end{tabular}

During the choosing of biocide additives there are the following requirements: they must not impair quality of fuels, characterized by prolonged action, detrimental effect on engine structural parts, fuel regulatory apparatus, reliability of filters and filter separators, to be toxic. Combustion products of these substances should not cause adverse effects on the environment [4].

Biocide additives may be soluble in fuels, and water cushion and destroy microorganisms in both phases [8].

Many biocide products have been tested abroad that meet the above requirements, there are the following: ethyleneglycol monometyl ether and Biofora F [8].

Ethyleneglycol monometyl ether - is anti water crystallization additive, with glycerol. However, it was found that glycerol actively contributes to the microorganisms, and without it ethyleneglycol monometyl ether reduces their growth. In addition to the fuel for air jet engines $0.1-0.15 \%$ by weight, substance concentrates in water up to $20 \%$, which not only prevents the formation of ice crystals, but also reproduction of microorganisms.

Biofor $\mathrm{F}$ after the penetration to oil product is concentrated in the free water. The mechanism of this substance action is also based on increasing of osmotic pressure. The effectiveness of the substance is in its lower concentrations in the water. This additive has the following drawback: when added to jet fuel is deposited on the blades of aircraft turbines and can cause them to corrosion due to increased acidity of water.

Long-term monitoring of fuel tanks coated with furan resins showed that microorganisms in these tanks is reduced [8].

There is well-known antiwater crystallization liquid "I-M", which is a product of association ethyl cellosolve and methanol. Liquid "I-M" is designated for use as additives to the fuel for the air jet engines, refueled aircrafts of civil aviation to decrease the probability of icing aircrafts and helicopters filters at low temperatures. We researched bactericidal properties of the additive that caused by containing of methanol [10].

There are used biocides that have the active components - cellosolve, compounds of nickel, copper and other metals, heterocyclic compounds in quantities 0,0001-0,005\% [7].

Due to increasing the range of biocide additives, there were studied bactericidal activity of such compounds dimethyl-dialkil-ammonium chloride $\left(\left[\mathrm{R}_{2}\left(\mathrm{CH}_{3}\right)_{2} \mathrm{~N}\right] \mathrm{Cl}\right)$ and dimethyl-alkyl-benzylammonium chloride $\left(\left[\mathrm{R}\left(\mathrm{CH}_{3}\right)_{2} \mathrm{NC}_{6} \mathrm{H}_{5}-\mathrm{CH}_{2}\right] \mathrm{Cl}\right)$ for aviation fuels - gasoline and fuel «TC-1» for air jet engines [8]. 
During the study of these compounds has been established [8] that the amount of $0.05 \%$ or more above mentioned additives reduce the growth of all microorganisms in the aviation gasoline and fuel «TC-1».

It was studied biocide activity of such compounds: zinc salts of synthetic fatty acids, mixed salts of zinc and mercury, acetic and oleic acids. With addition to jet fuel in concentrations of $0.05-$ $0.1 \%$, they found sufficient activity, reducing the number of microorganisms on $75-85 \%$. The salts of higher carboxylic acids of chrome, copper and lead, and also naphthenate of iron, copper and chromium were low-toxic [8].

Taking into account problem actuality of protection from both fuels accumulation of static electricity, and from microbiological contamination, was obtained complex additive that has antibacterial and anti-static properties. Mixtures of bactericidal and anti-static additives of different composition were studied; both bactericidal components applicated dimethyl-dialkil-ammonium chloride [8]. Simultaneously, this additive is an effective anti-static additive in concentration of $0.003 \%$, increases conductivity and reduces oil electrification during their motion [8].

It is set that the antiwater-crystallization additive PFA-55MB has high bactericidal effect for jet engines. Addition to jet fuel in an amount of $0,05-0,15 \%$ of PFA-55MB additive practically fully prevents development of microorganisms and corrosion of fuel tanks of jet engines. This additive is the most widespread abroad [9].

It was found that 8-hydroxyquinoline and disalicildenpropandiamin in addition to fuel for air jet engines brand «TC-1» in concentration 0,2 and $0,1 \%$ diminished growth of microorganisms accordingly on 88 and $75 \%$. Primary amines of $\mathrm{C}_{12}-\mathrm{C}_{15}$, which was added to the fuel in an amount of $1 \%$, diminished growth of microorganisms on $95 \%$.

Special experiments reflected that active biocide additives in the water-fuels systems there can be substances that do not dissolve in fuel, but soluble in water. Thus, the complete destruction of microorganisms in the environment in fuel «TC-1» was observed when injected into the water phase one of the following substances: $0,04 \%$ 1,2-diaminopropana or hexamethyldiamin, $0,12 \%$ ethylendiamin, hydroxylamine of hydrochloric acid or methylamine tartrate, $0,16 \%$ trimethylamine or $n$-butylamine.

Growth of microorganisms reducing on $98 \%$ is observed when the content in the water phase $0,08 \% n$-butylamine, etylendyamina, hydroxylamine hydrochloride or methylamine oxalic acid.

Inhibition of microorganisms increasing by 70,75 and $90 \%$ was observed in environment of fuel «TC- $1 »$ when in the water phase added respectively $0,24 \%$ chromium acetate, $0,16 \%$ chromium nitrate, $0,16 \%$ copper acetate $[9,10]$.

There is also known multifunctional additive IPOD (isopropyloktadetsylamin).

Bacteria fungicidity of additive on the base of gas condensates was studied. Unlike the other additives, it obtained from hydrocarbon fractions $(145-280){ }^{\circ} \mathrm{C}$ of gas condensates. Adding of the additive in amount of $0,1 \%$ destroyed microorganisms within $10-15$ days on $100 \%$.

Synthesized additive has not only antibacterial, but also antioxidant and anti-corrosion properties. The additive addition to final concentration of $0,1 \%$ prevents sediments in fuel on $80 \%$ $[5]$.

Katon FP 1.5 of the company ROHM AND HAAS (U.S.A.) is one of the highly effective biocides that used worldwide for various fuels. In the nomenclature of the International Union of Theoretical and Applied Chemistry, an active component of Katon FP 1.5 is defined as 5-chloro-2methyl-4-isotyazolin-3-one.

Today many foreign companies producing biocide additives to petroleum products, such as: «Bang and Bonsomer», «THOR», «ROHM AND HAAS» and others [8].

The authors conducted research on the efficiency of modern biocide additives (applications) of mentioned above foreign manufacturers. The research was conducted by the method of diffusion zone, which is testing the microbiological stability of jet fuel protected by antimicrobial additives 
with different concentrations in the Petri dish on nutrient dry agar for cultivation of microorganisms. Zones diameter of growth absence characterized the degree of test fuel stability.

It was used a mixture of aerobic bacteria (Pseudomonas, Bacterium, Mycobacterium) as a test cultures, allocated from the affected oil.

The research results of biological stability of aviation fuel RT, protected by biocide additives with the method of diffusion zone are shown in Table 6 and Fig. 7.

Table 6

Results of the experiment by the method of zonal diffusion

\begin{tabular}{|c|c|c|c|}
\hline \multirow{2}{*}{ Additive name } & \multicolumn{3}{|c|}{ Zone diameter, mm } \\
\cline { 2 - 4 } & $1 \%$ & $0,1 \%$ & $0,05 \%$ \\
\hline Formacide & 0 & 11 & 10 \\
\hline KATHON & 0 & 9 & 5 \\
\hline Grotan F10 & 0 & 7 & 9 \\
\hline Grotan OX & 25 & 14 & 6 \\
\hline Grotan TK 6 & 0 & 7 & 6 \\
\hline ACTICIDE KL & 0 & 10 & 24 \\
\hline ACTICIDE OX & 16 & 27 & 0 \\
\hline ACTICIDE MV14 & 36 & 30 & 2 \\
\hline Pure fuel RT(control) & 0 & 0 & \\
\hline
\end{tabular}

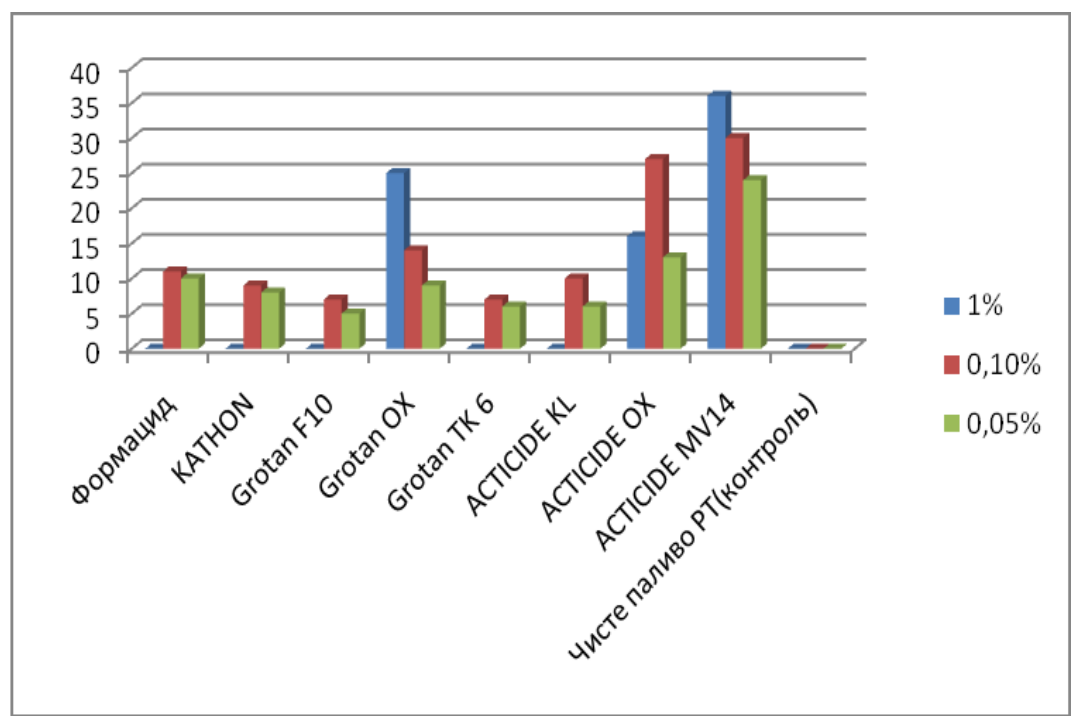

Fig. 8. Comparative distribution of research results of fuels biological stability, protected by biocide additives by diffusion zone method

So, this diagram represents that the best antimicrobial properties has the following additives: GROTAN OX, AKTICIDE OX, AKTICIDE MV14.

A host of problems will likely surface when uncontrolled microbial growth is allowed to develop. Microbial activity has been shown to cause degradation of fuel hydrocarbons. Flight safety also will likely be compromised, as well as increased maintenance and cost. Not all microorganisms, however, cause the same problems. 
Assessment or analysis of risk is a process for identifying hazards, assessing the probability of an event and its consequences. The ratio of risk objects and risky events makes it possible to determine the link between the biological risk in the field of the use of aviation fuel with technogenic and economic risks. Technogenic risk is a complex indicator of reliability of elements of technical means of operation. It expresses the probability of an accident or disaster during the operation of machines and mechanisms, in particular vehicles, and the implementation of technological processes. The source of Technogenic risk is the violation of the rules of operation of technical systems, the untimely conduct of preventive inspections. Economic risk is determined by the ratio of benefits and harm that society receives from a particular activity.

The authors of this work identified and systematized the consequences and the risks of microbiological contamination of aviation fuel (Fig. 9) [12].

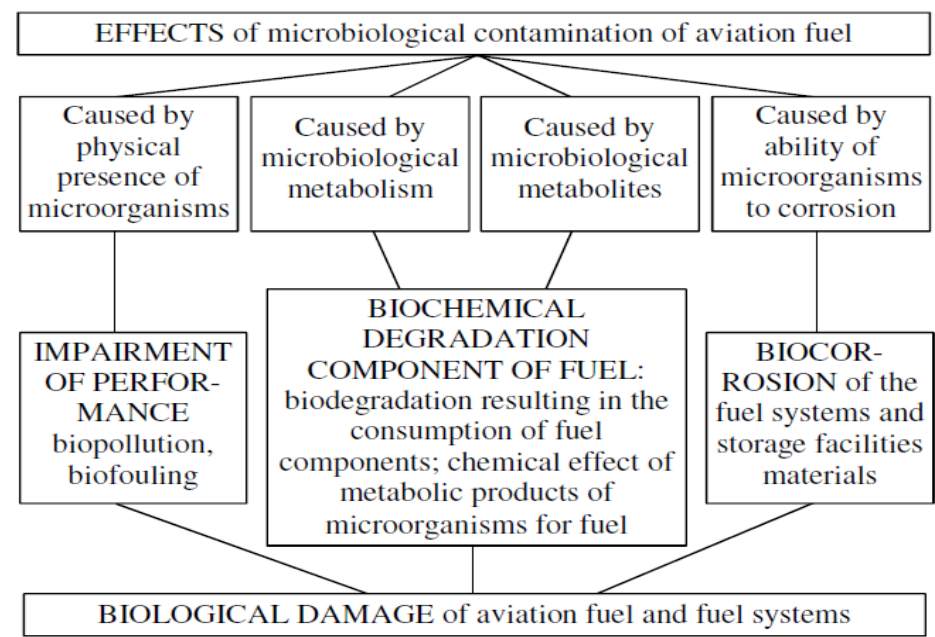

Fig. 9. The risks and consequences of microbial contamination of aviation fuels

Risk reduction is an action to reduce the likelihood of a negative event or mitigate the consequences of this event if it occurs.

A key factor is a multi-aspect approach to fuel hygiene to eliminate the inconveniences and costs associated with contamination of the fuel system. Each air operator should conduct his own risk assessment in order to determine the optimal regime.

An important component of this regime is the frequent checks of drainage systems, as well as regular testing and monitoring of microbiological contamination in the entire fuel system.

\author{
PЕФЕРАТ \\ Ірина Шкільнюк ${ }^{1}$, Сергій Бойченко ${ }^{1}$, Тетяна Кондратюк ${ }^{3}$, Наталія Шевчук ${ }^{2}$ \\ ${ }^{1}$ Національний авіаиійний університет, $i$ shkilniuk@ukr.net, \\ ${ }^{2}$ Національний технічний університет Украйни \\ «Київський політехнічний інститут імені Ігоря Сікорського», \\ ${ }^{3}$ ННЦ «Інститут біології та медицини» Київського національного університету \\ імені Тараса Шевченка \\ ІДЕНТИФІКАЦІЯ ТА ОЦІНКА БІОЛОГІЧНОГО РИЗИКУ \\ ПОСТАЧАННЯ АВІАЦЙНОГО ПАЛИВА
}

Основна увага в роботі приділена мікробіологічному забрудненню нафтопродуктів і паливних систем транспортних засобів і засобів експлуатації та зберігання. Обмежений обсяг нафтових ресурсів, впровадження стандартів IКАО і ІАТА, дотримання вимог авіаційної безпеки та експлуатаційної безпеки, економічні показники, фінансова прибутковість вимагають заснованого на оцінці ризику до 
поставок авіаційного палива. У процесі дослідження були виявлені, оцінені і систематизовані ризики і наслідки мікробіологічного забруднення авіаційного палива, його вплив на якість палив і хіммотологічної надійність авіаційної техніки.

Ключові слова: авіаційне паливо, біологічний ризик, мікробіологічне забруднення, гриби, біоплівка,паливна система, кислотність, мікробіологічна корозія, біоцид.

\author{
PЕФЕРАТ \\ Ирина Шкильнюк', Сергей Бойченко ${ }^{1}$, Татьяна Кондратюк, Наталья Шевчук² \\ ${ }^{I}$ Национальный авиационный университет, i_shkilniuk@ukr.net,

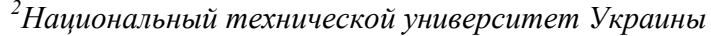 \\ «Киевский полетихнический институт имени Игоря Сикорского», \\ ${ }^{3}$ УНЦ «Институт биологии и медицины» Киевского национального университета \\ имени Тараса Шевченко \\ ИДЕНТИФИКАЦИЯ И ОЦЕНКА БИОЛОГИЧЕСКОГО РИСКА \\ ПОДАЧИ АВИАЦИОННОГО ТОПЛИВА
}

Основное внимание в работе сфокусировано на микробиологическом загрязнении нефтепродуктов и топливных систем транспортных средств и средств эксплуатации и хранения. Ограниченный объем нефтяных ресурсов, внедрение стандартов ИКАО и ИАТА, соблюдение требований авиационной безопасности и эксплуатационной безопасности, экономические показатели, финансовая прибыльность требуют основанного на оценке риска подхода к поставкам авиационного топлива. В процессе исследования были выявлены, оценены и систематизированы риски и последствия микробиологического загрязнения авиационного топлива, его влияние на качество топлив и химмотологическую надежность авиационной техники.

Ключевые слова: авиационное топливо, биологический риск, микробиологическое загрязнение, грибы, биопленка,топливная система, кислотность, микробиологическая коррозия, биоцид.

\author{
ABSTRACT \\ Iryna Shkilniuk ${ }^{1}$, Sergii Boichenko ${ }^{1}$, Tetiana Kondratiuk ${ }^{3}$, Nataliia Shevchuk $^{2}$ \\ ${ }^{1}$ National Aviation University, i_shkilniuk@ukr.net, \\ ${ }^{2}$ National Technical University of Ukraine "Igor Sikorsky Kyiv Polytechnic Institute», \\ ${ }^{3}$ Educational and Scientific Center "Institute of Biology and Medicine» \\ of Taras Shevchenko National University of Kyiv
}

IDENTIFICATION AND ASSESSMENT OF BIOLOGICAL RISK OF AVIATION FUEL SUPPLY

The work is focused on microbial contamination of refined petroleum products and fuel systems of vehicles and means of operation and storage. A limited amount of oil resources, the introduction of ICAO and IATA standards, satisfaction of safety and operational safety requirements, economic indicators, financial profitability, require the risk-based approach in aviation fuel supply. The risks and consequences of aviation fuels microbiological contamination, impact of it on fuel quality and chemmotological reliability of the aviation engineering, have been identified, evaluated and systematized during research.

Key words: aviation fuel, biological risk, microbiological contamination, fungi, biofilm, fuel system, acidity, microbiological corrosion, biocide.

\title{
REFERENCES
}

1. Shkilniuk I. The problems of biopollution with jet fuels and the way of achiving solution / I. Shkilniuk, S. Boychenko, V. Turchak // Transport. - 2008. - № 23 (3). - C. 253-257.

2. DOC 9977 «Guide to the supply of aviation fuel in civil aviation». - ICAO, 2012. - $46 \mathrm{p}$.

3. Characterization of microbial contamination in United States Air Force aviation fuel tanks / M.E. Rauch, H.W. Graef, S.M. Rozenzhak et al.]. // Journal of Industrial Microbiology and Biotechnology. - 2006a. - 33. - P. 29-36.

4. ISO 31000:2018. Risk management - Guidelines. Adopted: 2018-02. - ISO/TC 262 Risk management, 2018. $-16 \mathrm{p}$.

5. Orel S.M. Risk. Basic concepts / S.M. Orel, M.S. Maliovaniy. - Lviv: Publishing House NU «Lvivska politechnika», 2008. $-88 \mathrm{p}$. 
6. ASTM Standard D 6469 Guide for Microbial Contamination in Fuels and Fuel Systems. - ASTM International.

7. Aviation chemmotology: fuel for aviation engines. Theoretical and engineering bases of application: textbook / N.S. Kulik, A.F. Aksionov, L.S. Yanovskiy, S.V. Boichenko. - K.: NAU, 2015. - 560 p.

8. Shkilniuk I. Methodically organizational principles of biological stability providing of aviation fuel / I. Shkilniuk, S. Boichenko // Transactions of the Institute of aviation of Warsaw. - 2014. - № 4 (237). - P. 76-83.

9. Influence of microbiological contamination on acidity of traditional and alternative aviation fuels // Problems of chemmotology. Theory and practice of rational use of traditional and alternative fuel and lubricants: monograph // Sergii Boichenko, Kazimir Lejda, Vasiliy Mateychik, Petro Topilnitskiy. - [Under general ed. of Prof. S. Boichenko]. - K.: Center for Educational Literature, 2017. - P. 341-346.

10. Vasilieva A.A. / Influence of temperature on growth and viability of Hormoconis resinae $\mathrm{u}$ Phialophora sp., Developing in aviation fuels / A.A. Vasilieva, L.N. Chekunova, A.V. Poliakova // Magazine Mycology and Phytopathology. - 2009. - Vol. 43. - No. 4. - P. 312-316.

11. ASTM D3242 (2011) Standard Test Method for Acidity in Aviation Turbine Fuel. - ASTM International.

12. Shkilniuk Iryna. Microbiological control in the system of civil aviation jet fuel supply / Iryna Shkilniuk, Sergii Boichenko, Kazimierz Lejda / Science - Future of Lithuania. Transport engineering and management: Proceedings of the 19th Conference for Junior Researchers (May 6, 2016). - Vilnius, Lithuania, 2016. - P. 90 94. 